\title{
7.2 Реалізація організаційних рішень із забезпечення конкурентоспроможності інноваційних кластерів
}

Процес розвитку інноваційних кластерів характеризується відсутністю чіткого нормативно-правового поля, яке б надавало можливість ідентифікувати інноваційні кластери у загальній сукупності господарюючих суб’єктів, та визначало можливі механізми їхнього створення та розвитку. Це ускладнює координацію взаємодії учасників кластерного процесу, а також процесів пов’язаних зі створенням та розвитком інших інноваційно-орієнтованих підприємницьких структур (індустріальні парки, бізнес-інкубатори тощо) задля забезпечення конкурентоспроможності суб'єктів підприємництва як на внутрішньому, так та зовнішніх ринках. Вагомий вплив чинить наявність надзвичайно слабкого інформаційного поля, завданням якого є налагодження ділових комунікацій між державою та бізнесом стосовно питань забезпечення максимально можливої реалізації наявного інноваційного потенціалу, зокрема шляхом комерціалізації прогресивних інноваційних розробок. Тому питання побудови структурованого інституційного середовища, яке б визначало чіткі механізми розвитку саме інноваційних підприємницьких структур в Україні є одним із ключових пріоритетів стратегічного бачення забезпечення конкурентоспроможності суб'єктів підприємництва, які є учасниками інноваційних кластерів.

Динаміка життя в сучасному світі пояснює особливий інтерес суспільства до інновацій та креативно-інноваційної діяльності. Практичне застосування нових ідей у вигляді нових товарів та технологій став потужною рушійною силою економічного та соціального розвитку. Креативно-інноваційна діяльність призвела людство до нового, вищого ступеня розвитку. Це, у свою чергу, посилило процеси глобалізації суспільства, що призвело до швидких змін технологій, а також постійного пошуку нових підходів до управління суб'єктами господарювання. Для України це важливо для продовження інтеграції у світовий економічний простір, тому активізація інновацій набуває стратегічного державного значення. Реалізація інноваційного потенціалу передбачає комплексну модернізацію національної 
економіки України. Досягнення цієї мети можливо шляхом взаємної інтеграції таких соціально-економічних зв'язків, як «наука-освіта-виробництво» [318].

Стосовно України, то для більш точного оцінювання сучасного стану вітчизняної економіки, проаналізовано місце України у наступних світових рейтингах: глобальний індекс інновацій (Global Innovation Index), глобальний індекс конкурентоспроможності (Global Competitiveness Index) та індекс легкості ведення бізнесу (Doing Business) (табл. 7.2.1).

Таблиця 7.2.1

Місця України в глобальних рейтингах у 2017-2020 pp.

\begin{tabular}{|c|c|c|}
\hline Роки & $\begin{array}{c}\text { Місця України в рейтингах/ Загальна кількість оцінюваних } \\
\text { держав }\end{array}$ & $\begin{array}{c}\text { Значення } \\
\text { індексів }\end{array}$ \\
\hline \multicolumn{3}{|c|}{ Глобальний індекс інновацій } \\
\hline 2017 & $56 / 128$ & 35,72 \\
\hline 2018 & $50 / 127$ & 37,62 \\
\hline 2019 & $43 / 126$ & 38,50 \\
\hline 2020 & $47 / 129$ & 37,4 \\
\hline \multicolumn{3}{|c|}{ Індекс легкості ведення бізнесу } \\
\hline 2017 & $143 / 190$ & 63,90 \\
\hline 2018 & $80 / 190$ & 65,75 \\
\hline 2019 & $76 / 190$ & 68,28 \\
\hline 2020 & $64 / 190$ & 4,03 \\
\hline \multicolumn{3}{|c|}{ Глобальний індекс конкурентоспроможності } \\
\hline 2017 & $79 / 140$ & 4,0 \\
\hline 2018 & $85 / 138$ & 4,11 \\
\hline 2019 & $81 / 137$ & 4,11 \\
\hline 2020 & $85 / 141$ &
\end{tabular}

Джерело: побудовано на основі [314,315,316]

Дані табл.7.2.1 свідчать, що за показником Глобального індексу інновацій Україна займає опосередковані позиції, однак спостерігається тенденція до його покращення, тобто наявне незначне посилення оцінки інноваційного розвитку саме в глобальному економічному просторі протягом досліджуваного періоду.

У 2020 році Україну за оцінками експертів GII, які представляють Корнелльський університет (США), міжнародну бізнесшколу INSEAD, а також Світову організацію інтелектуальної власності (WIPO), за рівнем інноваційності економіки Україну поставили на 45 місце серед 131 країни. Серед країн із рівнем доходу економіки нижче середнього Україна посіла за цим індексом другу позицію. Першою тут визначено В’єтнам, третьою - Індію. До першої десятки за 
глобальним інноваційним індексом у 2020 році увійшли Швейцарія, Швеція США, Велика Британія, Нідерланди, Данія, Фінляндія, Сінгапур, Німеччина та Республіка Корея. Останньою, 131-ю за інноваціями кваліфіковано Смен.

Пандемія коронавірусу спричинила значний вплив на цьогорічну інноваційну діяльність та спричинила значне падіння світових економік. Водночас, уражаючи одні галузі, COVID-19 стимулює розвиток та фінансування інновацій в інших, особливо у сфері охорони здоров'я.

Вказані значення проаналізованих показників вказують на низький рівень зацікавленості держави у створенні, внутрішній комерціалізації та просуванні на зовнішній ринок власних інноваційних технологій, та у розвитку саме інноваційного підприємництва, що своєю чергою відображається на здатності суб'єктів підприємництва розвивати свій інноваційний потенціал. Вітчизняне законодавство не визначає дієвих механізмів податкового стимулювання розвитку інноваційного підприємництва, чинні програми стимулювання розвитку підприємництва не є системно орієнтованими, цільове фінансування в межах діючих програм не завжди є достатнім та не дозволяє задовольнити потреби господарюючих суб'єктів в повному обсязі. Наявна значна кількість бюрократичних перепон від процесів реєстрації до закриття підприємств.

Аби пришвидшити поступ у цьому напрямі, Кабмін запустив роботу Ради інновацій, покликаної стати ефективним інструментом взаємодії уряду, бізнесу та представників наукових кіл, а також майданчиком напрацювання важливих рішень у цій сфері. Проте вже й сьогодні можна говорити про значний інноваційний внесок України, винаходи й започаткування в різних галузях економіки, науки, культури, які стали відомими у світі:

1. ІT-індустрія. Згідно 3 даними платіжного балансу України, експорт комп'ютерних послуг у 2020 році зріс на 30,2\% порівняно з попереднім роком i склав 4,17 млрд дол. Відповідно обсяг сплачених до держбюджету України податків та зборів збільшився на 28\% і становив 16,7 млрд грн. Експорт комп'ютерних технологій стає одним із головних джерел надходжень бюджету i піднімає Україну у світових рейтингах. 
2. Літакобудування. Флагман українського літакобудування ДП «АНТОНОВ» розробляє чимало інноваційних програм, щоб передбачити нові потреби клієнтів, забезпечити технології, продукти та послуги, необхідні для завтрашнього аерокосмічного та оборонного ринків.

3. Ракетно-космічна галузь. Новітні технології, які роблять необов'язковим перебування людей на майданчику під час підготовки носія до запуску, взяті за зразок багатьма виробниками новітньої ракетно-космічної техніки. Провідним центром космічної галузі $\epsilon$ конструкторське бюро «Південне» та виробниче об'єднання «Південний машинобудівний завод» у м. Дніпро. Там створюють та серійно виробляють ракети-носії, космічні апарати, а також системи управління, орієнтації і траєкторних вимірювань. Великим досягненням українських фахівців стало створення космічних апаратів: «Січ-1», «Океан-О», «АУОС» та «Мікрон», ракет-носіїв «Зеніт-3SL», «Зеніт-3SLБ» та «Циклон-3».

4. Культуран сфера. У серпні 2019 року розпочав роботу Офіс культурних інновацій, який заснували громадські організації в партнерстві $з$ державними та приватними інституціями. Ключове завдання Офісу - відкрити потенціал української культури й науки за посередництва інноваційної платформимаркетплейсу «Український національний інтелект» UNI.ua.

6.Банківська сфера. 3 серпня 2020 року СЕП запрацювала в режимі 24 години на добу 7 днів на тиждень. Така новація дасть можливість проводити чутливі до часу платежі, а також сприятиме розширенню доступу клієнтів до фінансових послуг та зростанню частки безготівкових розрахунків.

За версією видання «Власть денег» наприкінці 2019 року список 20 найбільш інноваційних компаній України очолили компанії Сільпо, Нова Пошта, WOG, DATA Group, Moneweo. У свою чергу, за рейтингом журналу «ТОП-100» (Новостной портал Украины Delo.ua, 2020), що формувався за підсумками 2019 року лідерами 50-ти інноваційних компаній в Україні стали такі: Метінвест (вид діяльності - промисловість), Сільпо (вид діяльності - рітейл), ДТЕК «Нафтогаз» (вид діяльності - енергетика та нафтогаз), АВК (вид діяльності - FMCG), MХП (вид діяльності - АПК), Альфа-Банк України (вид діяльності - фінанси), Taruan 
Group (вид діяльності - будівництво), Київстар (вид діяльності - IT та телеком), Фармак (вид діяльності - фармацевтика) та Нова Пошта (вид діяльності транспорт та логістика) [313].

Отже, можна прослідкувати, що найбільша частка інноваційних компаній в припадає на сферу технологій, фармацевтику, машинобудування, альтернативну енергетику, фінанси, вантажоперевезення, паливно-енергетичний комплекс тощо.

В Україні сьогодні інституційного середовища для кластерних об'єднань підприємств немає, так як кластери навіть не ідентифікуються у вітчизняному господарському законодавстві як самостійна господарська одиниця, що відображається на відсутності офіційної статистичної інформації щодо стану та динаміки їхнього розвитку у регіонах. Тому запропонований приклад механізму інформаційно-комунікаційного супроводу розвитку інноваційних кластерів в Україні, який спрямований на системне удосконалення інстутуційноорганізаційних основ розвитку інноваційного підприємництва шляхом встановлення чітких алгоритмів створення та ідентифікації інноваційних кластерів. У рамках запропонованої структури інституційно-організаційного середовища розвитку кластерів та із урахуванням попередніх досліджень, виділено можливі технології створення кластерів (кластерний сценарій - технологія створення кластера (кластерний сценарій) - сукупність нормативно-правових, інвестиційних, фінансових, інформаційних та інших організаційних рішень, що є результатом компатибільних дій усіх зацікавлених учасників спрямованих на створення нових та розвиток існуючих кластерів), які є об’єднаними у два блоки: технології у секторі державного підприємництва - вихідним джерелом стимулювання є державні інституції та технології у секторі приватного підприємництва - джерелом вихідного стимулювання є самі суб'єкти підприємництва. Визначено, що у секторі державного підприємництва можливі наступні сценарії створення кластерів: сценарій «верхньої ланки» та «регіональний сценарій». На рис. 7.2.1 представлено графічну модель технології реалізації організаційних рішень із забезпечення інноваційних кластерів в системі національної економіки. 


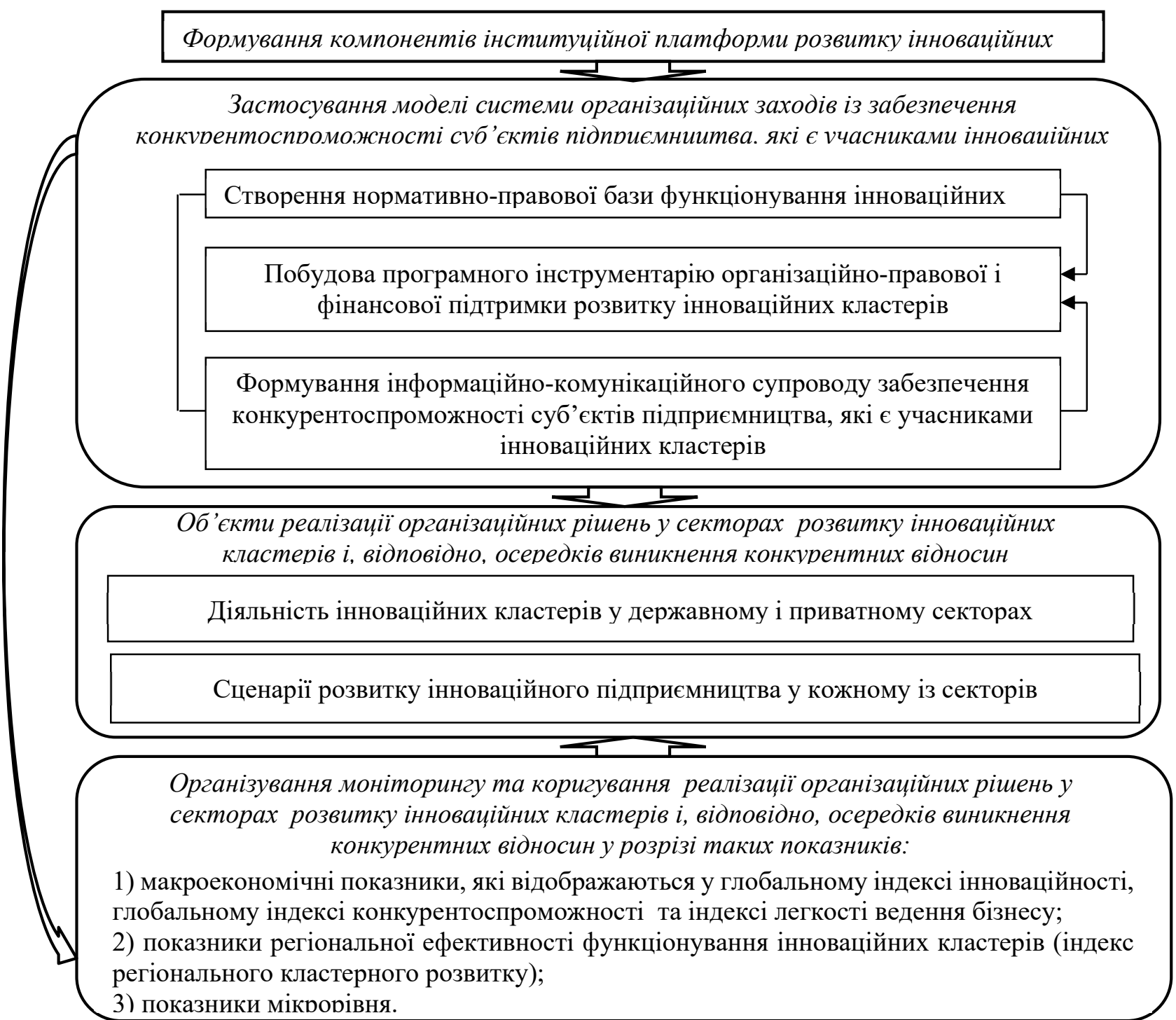

Рис. 7.2.1. Запропонована процесно-структурна модель технології реалізації організаційних рішень із забезпечення конкурентоспроможності інноваційних кластерів національної економіки

У теорії сучасного менеджменту організаційні заходи передбачають формування та переформування організаційних структур, розподіл та перерозподіл повноважень та обов'язків між суб'єктами управління, створення та коригування правил та процедур. У наведеній на рис. 1 процесно-структурній моделі технології реалізації організаційних заходів із забезпечення конкурентоспроможності інноваційних кластерів у системі національної економіки передбачено не лише формування компонентів інституційної платформи розвитку інноваційних кластерів, але й моніторинг та регулювання наслідків впроваджених рішень. Варта зазначити, що етапи представленої моделі застосовуватимуться на різних фазах управлінського процесу під час виконання функцій організування, контролювання 
та регулювання діяльності інноваційних кластерів в системі національної економіки.

Важливою сполучною ланкою між етапами застосування представленої моделі системи організаційних заходів та їхнім регулюванням $є$ моніторинг об’єктів реалізації організаційних рішень у секторах розвитку інноваційних кластерів та осередків виникнення конкурентних відносин. Його інформативність значною мірою залежить від методів та джерел акумулювання та обробки управлінської інформації, а також повноти охоплення факторів, які впливають на ефективність організаційних рішень із забезпечення конкурентоспроможності суб’єктів підприємництва, які є учасниками інноваційних кластерів в системі національної економіки. За результатами проведених досліджень, повноту відомостей, які необхідні для забезпечення інформативності моніторингу, відображатиме комплекс показників: макроекономічні показники, які відображаються у глобальному індексі інноваційності, глобальному індексі конкурентоспроможності та індексі легкості ведення бізнесу; показників регіональної ефективності функціонування інноваційних кластерів (індекс регіонального кластерного розвитку); показників мікрорівня.

Процес ефективної кластеризації з урахуванням сучасних економічних реалій потребує глибинного системного підходу спрямованого на повну трансформацію наявного інституційного середовища шляхом його функціональної структуризації. Така функціональна структуризація повинна передбачати чітке виокремлення всіх необхідних для ефективного розвитку кластерної парадигми процесів: правового забезпечення - необхідного для чіткої ідентифікації інноваційних кластерів серед інших господарюючих суб'єктів, програмного забезпечення - необхідного для стимулювання та зацікавлення суб'єктів підприємництва у створенні інноваційних кластерів, інформаційного забезпечення - необхідного для організації ефективної взаємодії всіх учасників процесу створення інноваційних кластерів та надання інструментарію аналітичного оцінювання їхньої практичної корисності економіки держави в цілому. 